\title{
APPROACHES TO URBAN REVITALIZATION POLICY IN LIGHT OF THE LATEST CONCEPTS OF SUSTAINABLE URBAN DEVELOPMENT ${ }^{1}$
}

\author{
Serhii Horbliuk', lia Dehtiarova²
}

\begin{abstract}
The article substantiates the essence and necessity of the use of innovative approaches to the formation and implementation of public policies of urban revitalization in the context of the latest concepts of urban development, namely: Compact City, Green City, Smart City, Creative City, Inclusive City, Cittaslow, Happy City, Learning City. The relevant proposals on the innovation policy of revitalizing cities are brought forward based on the analysis of the provisions of each of the chosen concepts. It is determined that there does not exist a single city where only one of the latest concepts of city development was implemented. In practice, we observe the multivectorness and combination of urban policies, which came to replace traditional sectoral views. Regarding the policy of urban revitalization, innovative approaches focus on the transformation of degraded areas into urban environments favourable for human life and activities in line with the needs and interests of their inhabitants. Revitalization should be considered both in terms of its impact on a specific degraded area and as having long-term synergetic effects on the city as a whole. It was found that the basis for innovative policies of urban revitalization is laid by human-oriented programmes of sustainable renewal of areas. The programmes are premised on taking into account a variety of concepts and combining a number of activities, specifically: organization of a compact multifunctional environment (Compact City); formation of an ecologically friendly environment for human life and activities (Green City); arrangement of urban space taking advantage of modern technologies and innovations (Smart City); creating conditions for life, activities and cooperation of creative people (Creative City); ensuring a full-fledged multidimensional inclusion of all the inhabitants (Inclusive City); realization of the internal potential of an area depending on local identity (Cittaslow); raising the level of public and individual happiness (Happy City); promotion of the culture of lifelong learning of all the inhabitants (Learning City). It is noted that innovative solutions for overcoming the crisis phenomena of degraded urban areas should be individualized depending on the local specificity and potential, the state of economic, physical, human and other capital of a particular city. In this case, the development of human capital of an area is increasingly becoming the key factor of its renewal, which presupposes organization of the inhabitants' training, improving their qualifications and skills. It was substantiated that the revitalization policy is expedient to develop from the perspective of ensuring multiplicative impact on the development of a city as a whole. The efficiency of the policy implementation depends on the leveraging of resources (financial, intellectual, etc.) from different sources through partnerships. The main criterion of policy effectiveness is the ability of a revitalized urban area to develop sustainably, satisfying the needs of all stakeholders. Indicators of the policy success is not only the living standards and quality of life of the inhabitants, but also the condition of the natural environment, levels of tolerance, trust, empathy, social cohesion, education, happiness, etc.
\end{abstract}

Key words: urban revitalization, sustainable development, Compact City, Green City, Smart City, Creative City, Inclusive City, Cittaslow, Happy City, Learning City.

JEL Classification: O18, O31, R11

\footnotetext{
Corresponding author:

${ }^{1}$ National Academy for Public Administration under the President of Ukraine, Ukraine.

E-mail: serhii.horbliuk@gmail.com

ORCID: https://orcid.org/0000-0002-5031-2497

${ }^{2}$ National Academy for Public Administration under the President of Ukraine, Ukraine.

E-mail: iyadeht@gmail.com

ORCID: https://orcid.org/0000-0002-0807-961X
}

\footnotetext{
${ }^{1}$ This research was supported by the International Visegrad Fund within the scope of the Visegrad Scholarship Program in the academic year 2020/2021.
} 


\section{Introduction}

The modern understanding of a public policy of urban revitalization is focused on sustainable development of urban areas, which requires integrated actions in all spheres of city life (community, economics, space, and environment). The evolution of the policy in question was marked by a low efficiency of public-administrative decisions which had a fragmented impact, being developed for the short term. Nowadays, the need for comprehensive programmes of revitalization of urban areas is becoming more relevant. Implementation of such programmes would inevitably lead to longterm changes on the basis of consensus of Sustainable Development Goals and ways to attain them. Besides, it is necessary to take into account the complexity of an urban organism, the role of each part of the city in its general structure, as well as correlation between urban problems and capabilities.

The integrated measures for revitalizing degraded areas must comply with the concept of urban development and be innovative. Thus, the success of urban revitalization increasingly comes to depend on non-standard approaches to overcoming the crisis phenomena of territorial development. Building sustainable communities and ensuring a high quality of their life are becoming urban revitalization priorities, while the latest concepts of urban development define the ways to achieve this by forming a smart, creative, and happy urban environment. When developing innovative approaches to the formation and implementation of public policies of urban revitalization, it is necessary to consider the specifics of the relevant concepts. In addition, this should serve the purpose of better evaluating and using the potentials of degraded areas during their renewal.

Therefore, the aim of the article is to substantiate approaches to the formation and implementation of the public policy of urban revitalization based on the latest concepts of urban development, as well as the framework conditions for their application. In order to achieve the aforementioned aim, the following tasks were formulated: to analyse the state of the art in urban development concepts; to establish a set of measures for the revitalization policy, based on the vision of a city's development in general; to develop innovative practical proposals for degraded areas revitalization.

\section{Previous research review}

The past decade decisively consolidated the understanding of urban revitalization as a tool of the urban policy of a balanced development of crisis territories. P. Roberts (2017) notes that when applying the tool, coordinated action of public administration and private partners should be taken in compliance with the economic, social, environmental and political principles laid down in the sustainable development concept.

The growing attention to the sustainability of cities influenced the policies and practice of their renewal. The search for new methods to revitalize degraded urban areas in a sustainable way has led to the creation of the concept of a sustainable revival of cities (Korkmaz, Balaban, 2020). After all, it is mistaken to think that while revitalizing a city one can neglect the balancing of economic, social and environmental interests, focusing solely on the achievement of short-term results. Thus, the concept of urban revitalization has become the key driver of cities' sustainable development (Akotia, Opoku, 2018).

However, as J. Kusiak (2019) emphasizes, most of urban revitalization programmes still lack a holistic systemic dimension. The economic, environmental, and social aspects of the existing revitalization programmes will always remain interconnected, often being contradictory, though. In addition, poor coordination between different tiers of public administration results in that the revitalization programmes are essentially stuck in the framework of a unilateral approach. Consequently, this can lead to negative effects of urban areas development that might cause the emergence of new crisis phenomena or deepen the existing ones.

A successful city renewal requires a multifaceted strategic approach that includes elaboration of both local and regional legislative instruments, to be designed within multi-sector and interdepartmental partnerships (Yi, Liu, Lang, Shrestha, Martek, 2017). In the context of revitalization, participation of the key actors in the development and implementation of a relevant policy is a factor, fundamental for achievement of the planned results and the sustainability of revitalization projects (Akotia, Opoku, 2018). It is necessary to balance the interests of all stakeholders in urban revitalization, so that the developed measures would increase their capacity (Zheng 2017). This applies, among other systematic thinking aspects, to foresight of sustainability and social learning processes, whereas collective vision, mediation, expansion of community capabilities can become immediate drivers of a sustainable revitalization of urban areas (Wolfram, 2019).

S. Lehmann (2019) emphasizes the relevance of new knowledge and justification of the best ways to implement the urban revitalization policy, while avoiding common mistakes (disregard of public transport, improvement in the life of a limited category of residents, excessive gentrification and loss of urban identity, etc.). Urban revitalization varies depending on the city size, type of problems, and socio-ecological context in every particular case. Although revitalization projects which have been realized in world-famous places are well described, there is still a gap in characterizing revitalization processes aimed at improving the quality of life in smaller settlements, such as medium-sized 
cities (Jaszczak, Kristianova, Pochodyła, Kazak, Młynarczyk, 2021). At the same time, according to $\mathrm{K}$. Ruming (2018), it is worth focusing on the impact of the revitalization of a degraded urban area on the development of the city as a whole, and the possibility of replicating the territorial management innovations introduced in other urban areas.

At the present stage, urban revitalization tends more often to unleash the potential of territories, taking into account the latest trends in urban development. D. Boussaa in his scientific work (2018) examines the problems of cities' historical centres in the course of their renewal, including the way they can be used to enhance urban identity. A. Garcia-Fuentes, A. Quijano, De Torre, R. Garcia, P. Compere, C. Degard, I. Tome (2017) presented models of sustainable urban revitalization that determine an integrated holistic process of urban ecosystem transformation on the smart city principles, including stable urban mobility and integrated infrastructure facilities and processes. The issue of using creative industries for urban areas revitalization was investigated by $\mathrm{O}$. Oyekunle (2017), in particular the policy of developing creative diversity and social integration in cities, the potential of creative projects for expanding the opportunities and involvement of the community.

Alongside with that, there are various visions and practices of sustainable urban development with regard to modern adaptation to climatic changes. In this sense, it is worth mentioning a scientific study of D. Tubridy (2021), who considers the relationship between urban revitalization and the development of green economy. These and other scientific results indicate the need to improve the instruments of the urban revitalization policy, when devising a strategic vision of urban development and the role which degraded areas can play in future.

The conducted analysis proved that there exists a range of scientifically grounded urban development concepts which reflect the main approaches to urban policies. The modern vision of urban development is based on the concepts of compact, green, smart, creative, inclusive, slow, happy, etc. cities, which is confirmed by numerous scientific publications (Table 1).

Note should be made of several well-known scientists whose thorough works have had a fundamental value for the formation and development of the relevant concepts, in particular: J. Jacobs (Compact City), M. Bryx (Green City); R. Giffinger (Smart City); Ch. Landry, R. Florida (Creative City); A. V. Anttiroiko, M. de Jong (Inclusive City); H. J. Jang, T. Jung (Cittaslow); Ch. Montgomery (Happy City); as well as representatives of the UNESCO Institute for Lifelong Learning (Learning City). However, the issue of forming an urban revitalization policy built on the above concepts requires a separate study. In the result, the innovative urban development concepts should lay the basis for planning innovative approaches to urban renewal.
Table 1

The coverage of the latest urban development concepts in scientific articles, according to GoogleScholar platform data of 2011-2020 (author's development)

\begin{tabular}{|l|c|}
\hline Concept of urban development & $\begin{array}{c}\text { Approximate number } \\
\text { of scientific articles }\end{array}$ \\
\hline Compact City & 16700 \\
\hline Green City & 16400 \\
\hline Smart City & 42000 \\
\hline Creative City & 16200 \\
\hline Inclusive City & 4680 \\
\hline Cittaslow & 2900 \\
\hline Happy City & 2120 \\
\hline Learning City & 2630 \\
\hline
\end{tabular}

Source: GoogleScholar, https://scholar.google.com.ua

\section{Results and discussion}

\section{Compact City}

This concept is to ensure a high housing density of an urban area, avoiding monofunctional zones. It is an alternative to a gradual urban sprawl. The concept is based on the vision of a city of short distances between the places of living, work, rest, public spaces, which is convenient for the inhabitants. Features of a compact city were a subject of research conducted within the project "Compact City Policies: A Comparative Assessment" (OECD 2012). As a result, the following general characteristics of a compact city policy were identified: density and close proximity; public transport systems connecting urban areas; availability of public services and jobs.

For a better understanding of the compact city concept, it is worth drawing attention to the work of J. Jacobs, the author of a famous book "Death and Life of Big American Cities" (Jacobs, 2016). Regarding the city as a complex organism, she claimed that urban elements are closely connected and interact with each other. Her vision of urban development was based on planning viable streets where "social eyes" are their natural owners, guards of order and public security. In accordance with the recommendations formulated by J. Jacobs, revitalization of degraded urban areas should provide for:

- a comprehensive planning of an urban area, aimed at combining various functions and infrastructure facilities, without separating, for example, a residential zone from the areas of recreation or work; this functional differentiation is to ensure the living of various categories of people in the area, permanent street movement, and the presence of "social eyes";

- ensuring the density of small-size quarters with crossroads, where residents mainly walk, or cycle; in this case, a mass transfer of residents to the outskirts of cities and suburban areas is undesirable, since it is necessary to raise the density of the urban space and 
provide the presence of "social eyes" in the area at any time;

- the need to preserve, among other things, old buildings (not only monuments of cultural heritage), which is stipulated by the intention to ensure the presence in the urban space of residential facilities adjusted for coexistence of people with unequal levels of income; because in urban areas consisting of modern buildings only, soon there appear commercial and office premises, designed for wealthy inhabitants, which significantly reduces the functional diversity of the area and entails spatial segregation.

Thus, revitalization of a city should enhance its attractiveness, forming stable interconnections between the inhabitants of a particular territory. The priority objectives are: concentration of infrastructure facilities of different functionality, street traffic planning, and organization of an effective public transportation system. Ultimately, it is supposed to create benefits for the residents of a degraded area and ensure its future self-sufficiency. The introduction of the compact city concept requires significant financial expenses (in case it is necessary to redesign and reconstruct the existing infrastructure, build new facilities, etc.), and substantial organizational changes in the use of urban space and distribution of its functions.

\section{Green City}

Improving the quality of life in contaminated and deteriorated urban areas presupposes their transformation into greener and environmentally resistant territories. Currently, the green city concept relates to building a compact city, rather than expansion of urban areas, aiming to save energy resources and reduce adverse impact on the environment. Creation of a green city requires a targeted sustainable urban development policy which provides a wide range of pro-ecological activities related to the four major components of the urban environment (Bryx, Lipiec, Rudzka, 2015; pp. 42-43):

- air (the city authorities take action to prevent or minimize air pollution, since the negative situation in this sphere leads to a higher morbidity rate, prevents job creation and organization of leisure activities);

- water (pure water is one of the foundations of life, therefore, it is necessary to meet the needs of inhabitants and business entities in this resource; at the same time, the use of water always leads to the sewage treatment problem in the city);

- space (public spaces are areas where people have the opportunity to spend their time, communicate with others and form communities; these places create adequate conditions for quality recreation and business activity of the inhabitants);

- green plantations (normally they form such public spaces as parks and miniparks, gardens, etc.; these areas are crucial in the struggle for fresh and unpolluted air, which is also valuable for the inhabitants' mental health).
The essence of the green city concept is revealed in the European Commission project "Green Cities - Fit for Life". In the framework of the project, a European Green Capital is determined annually (European Green Capital Award), based on the following criteria: local actions to prevent the effects of global climatic changes, local transport, urban green zones and sustainable use of land, nature and biodiversity, quality of city air, noise level, waste generation and management, water consumption, sewage treatment, eco-innovation and stable employment, energy characteristics of the territory, and urban environmental management. In recent years, the award was granted to several European cities - Ljubljana (2016), Essen (2017), Nijmegen (2018), Oslo (2019), Lisbon (2020), Lahti (2021) (European Green Capital Secretariat, 2021) which demonstrated the attainment of high environmental standards and set an example of sustainable development.

In the context of a green urban policy, urban revitalization should be considered in two dimensions. In the case of drastic degradation of the environment (post-industrial areas, former port territories, etc.), radical revitalization measures are needed. They require significant investment for environmental construction, the development of a circular economy, and re-designing of areas by implementing large-scale projects of nature management. On the other hand, in a situation of a satisfactory environment, moderate revitalization measures are put in place. These measures should improve the environmental condition of an area through expansion of green plantations, arrangement of pedestrian and bicycle paths, restriction of road transport, implementation of energy-saving solutions, proper waste management, etc. Some urbanists point out that the distance from any residential place to the nearest green zone should not exceed $500 \mathrm{~m}$, regardless of the direction in which a pedestrian is moving (A. Brdulak, H. Brdulak, 2017; p. 12). The planning of actions depends on local challenges; however, it is logical, while revitalizing a degraded area, to combine pro-ecological educational activities with economic and social measures in order to achieve a synergetic effect.

\section{Smart City}

The construction of a smart city is based on the application of new knowledge, technologies and innovations to arrange a multifunctional urban space with low energy consumption. Also, smart cities are aimed at attracting human and social capital for urban development, pursuing the goal of ensuring high living standards. Based on the benchmarking of mediumsized European cities, a team of experts under the leadership of Prof. R. Giffinger from the Technical University of Vienna presented a model of a smart city. According to the model, a city is considered to be smart, when it meets the following 6 characteristics (Giffinger, Pichler-Milanović, 2007; pp. 11-12): 
- smart economy which involves innovative entrepreneurial spirit, development of industries with a high added value, a flexible labour market, and international cooperation;

- smart people who are characterized by a high level of qualification, lifelong learning, social diversity, creativity, openness and participation in public life;

- smart governance, characterized by accessibility and proper quality of public services, public participation in management decision-making, implementation of effective urban development strategies;

- smart mobility which is measured in terms of the presence of the latest information and communication infrastructure, innovative and safe transport and logistics systems;

- smart environment which consists in sustainable management of natural resources and environmental protection, modern methods of a rational natural resource use;

- smart living due to the activities of cultural institutions, quality living conditions (healthcare, security, housing), educational opportunities, tourist attractiveness of the area, and social cohesion.

The policies of urban revitalization must take into account the above elements. Ensuring the functioning of a smart city is a long-term process that requires rethinking of all spheres of the city life. When overcoming the crisis phenomena of degraded urban areas, attention should be focused on: the development of modern facilities of urban infrastructure, in particular environmentally friendly types of transport and institutions promoting business (business incubators, industrial parks, entrepreneurial zones, etc.); introduction of energy-saving technologies and the use of renewable energy sources; creation of integrated systems of public security and information networks that collect, process and analyse data and respond automatically to events; organization of public spaces with the use of information and communication technologies; extending green plantations, improvement of waste management systems; realization of other projects of environmental value. The implementation of the smart city concept through revitalization of degraded areas depends on the introduction of management innovations, and coordinated actions of all stakeholders to form an urban environment that is competitive, attractive for business and inhabitants, and capable of addressing future challenges.

\section{Creative City}

This approach to urban development is based on culture, intellectual property, and creativity. Accordingly, developed cities are characterized not only by innovations, but, above all, by the uniqueness of the environment where social capital is formed around culture and art. Therefore, the objective of urban policy is to form favourable conditions for residence, recreation, professional activities and cooperation of creative people. R. Florida (2012) believes that the "Creative Class" is a key urban resource that defines the city's competitiveness and plays the leading role in the processes of development and revival of its areas. The scientist interpreted the creative city as the living environment for the Creative Class. The creativity of cities is evidenced by availability of qualified creative workers (the Creative Class) who stimulate the development of the city and for whom the city authorities create an adequate atmosphere, promote creativity and cultural diversity. According to R. Florida, the city will be attractive to the Creative Class subject to the development of three components (the $3 \mathrm{Ts}$ ): Technology, Talent, and Tolerance, which are the drivers of the creative city's growth (Florida 2012).

Ch. Landry was the first to scientifically substantiate the importance of creativity and its impact on urban development. He also introduced the term of 'creative city' as a response to sharp economic and social changes that took place in cities. During the crisis of industrial cities, it is the culture industry that has been a salvation for many of them, using its specific niches, local advantages and cultural heritage. The scientist defined the features of the creative city (Landry, 2012) as follows: political will and leadership in the vision of the creative city as a living organism, taking into account the needs of the local community, the general situation and urban development trends; social diversity and access to the talent base, which positively affects the city's creative potential; organizational culture that should be trustworthy, promoting establishment of horizontal social ties and knowledge sharing; local cultural identity which is a prerequisite for civic activity, the sense of community and concern for the city environment; urban space and infrastructure which allow residents to expand their social circle; dynamics of networking which indicates the ability of the city to form partnerships, to learn and generate innovations. The formation of a creative city is closely linked to the urban space revival and development, since the creative sector is often found in abandoned and degraded city areas.

A comprehensive approach to the development of a creative environment has a great potential for urban revitalization. Its introduction requires combining a cultural policy with socio-economic measures, and spatial planning. At the same time, the crucial point for building a creative city is investment in human and social capital, the sphere of culture. In this regard, revitalization measures are directed to the formation of hard and soft infrastructure. The hard infrastructure presupposes a proper functioning of public institutions, housing facilities, street-road and engineering networks, etc., which reflect the physical characteristics of an area. The soft infrastructure consists of projects of support to talented people and creative industry enterprises (audiovisual works, tourism, sports, literature and 
publishing, cultural heritage, performative and visual art, design, programming, etc.). During revitalization, it is important to develop public creative spaces, set up platforms for cooperation and dialogue between creative people, and stimulate the emergence of creative clusters.

\section{Inclusive City}

This concept involves focusing of urban policy on all segments of the population and their needs, countering, in the first place, social exclusion. The European Commission regards exclusion as a process, during which individual members of the community are ousted to the margins of public life due to the lack of basic skills of functioning in society or education (Eurostat $2010 ;$ p. 7). This pulls them away from jobs, income, opportunities for personal development, and limits their social interrelations. However, the urban inclusion need should not be considered from a social perspective alone. In terms of monetary income and employment, inclusion is an economic problem, and it is materially unsecured people who need support to fully participate in the economic life of an inclusive city. In case inclusion centres around access to natural resources, it is possible to distinguish its wider environmental interpretation. In addition, when religious, gender, cultural or age aspects are considered, inclusion acquires social and moral characteristics. In its turn, political inclusion is indicative of participation of all population groups in public and management processes of the inclusive city (Antiroiko, de Jong 2020; p. 16). However, inclusion should not be limited solely to disadvantaged or marginalized groups; it should include other social layers which are usually not taken into account when developing urban policies (e.g., students of local educational institutions, families with children, older people).

In accordance with the urban revitalization priorities, multidimensional urban inclusion is not a mere prerequisite for justice, availability and quality of public services, and well-being for all the inhabitants, but also an opportunity to find untapped local potential for territorial development. Thus, it is necessary to support the unemployed and socially excluded population groups through arrangement of various professional development activities, social integration events, motivation and psychological assistance. Improvement of the living environment and accessibility of public spaces (including elimination of barriers that complicate the movement of persons with disabilities), stimulating the growth of the local economy, ensuring safety in a degraded area, development of public transport can enhance urban inclusion, improving the interaction among the inhabitants and business entities. On the other hand, the expansion of the inclusive city can be associated with the projects of support to small business within various communities (in the first instance, ethnic groups, students, people of pre-retirement and retirement age, young parents), crowd funding of public projects or business ideas of freelancers. In summation, revitalization activities of inclusive cities should be directed to all categories of inhabitants of degraded areas, including their involvement in public life and motivation to self-organization and cooperation.

\section{Cittaslow}

The concept relates to small cities that seek to provide their inhabitants with quality living in harmony with nature, the environment, and local cultural traditions. The Cittaslow movement aims to preserve the unique nature of every city, develop the internal potential of territories based on local identity. Due to a slowdown in the intensity of urban life, a friendly atmosphere in the city is formed as an alternative to the urbanized environments of large cities where a fast rhythm of life does not allow people to enjoy their lives. In order to become a member of the International Network of Cities of the Good Life Cittaslow (Cittaslow International head office 2021; Jang, Jung 2015), it is necessary to develop the following areas of urban policy: protection of the environment by providing green spaces and introducing renewable energy sources; maintenance of the monuments of historical and cultural heritage and their aesthetic renewal; establishing conditions for sustainable urban mobility that meets the needs of individuals and businesses; organization of recreation of the inhabitants and building of the appropriate infrastructure; facilitating the development of local tourism and hospitality industry; promoting local products, including the support for organic agriculture, traditional crafts and cuisine; raising general and pro-ecological awareness of the inhabitants; strengthening social cohesion and partnership.

This concept can show along which lines degraded urban areas should be revitalized, with a focus on the quality of life of the inhabitants and the creation of preconditions for sustainable urban development. Also, its major preoccupations are the authenticity of local landscapes, traditions, healthy foods, peace and quiet, closeness to nature, self-employment, and leisure. The bottom line is that cities should be concerned about local identity and enhance its significance in their policies.

Therefore, urban revitalization programmes rely on local marketing strategies, fostering the uniqueness of a particular area. The city inhabitants become active participants in urban changes, because the slowed pace of life implies, first of all, an abundance of measures that promote personal fulfillment and formation of social capital (educational and cultural programmes; support of traditional crafts, folk art and trades, etc.). These activities contribute to the development of tourism, oriented to acquaintance with local culture and traditions. However, without incentives for a sustainable growth of the local economy and infrastructure, it is impossible to ensure continuity of development, cultural 
diversity, and maintaining distinctive character of areas. Combining within the revitalization programmes of cultural, economic, spatial and other projects is supposed result in a decline in the unemployment rate and a decreased migration of people to large cities. Especially since the renewal of degraded urban areas is to serve the purposes of social cohesion, promotion of values, educational development, and maintaining a balance between traditions and innovations.

\section{Happy City}

According to this concept, the main benchmark of urban development is the city inhabitants' subjective sense of happiness, their satisfaction with what is happening to them in the city. Therefore, urban policies should be concerned about the positive psycho-emotional state and moral conscience of the city inhabitants. Happy cities are also centres of creativity, innovation and social entrepreneurship. Ch. Montgomery (Montgomery 2013; p. 48) notes that a modern city is to make its inhabitants happy through an inspirational environment of empathy and cooperation. To that end, in his opinion, after satisfaction of basic human needs in food, housing and safety, it should:

- seek to maximize the enjoyment and minimize the hardships of the inhabitants, and take care of their health; - give the inhabitants a real freedom to live, move around, and build their lives as they want;

- form the inhabitants' resistance to all types of economic and environmental shocks;

- be fair in distribution of space, public services, mobility opportunities, entertainment, as well as challenges and charges (e.g., parking fees);

- create conditions for building and strengthening all types of interpersonal relations (friendship, family, professional activity, leisure) which give meaning to the inhabitants' lives.

The pursuit of happiness under the conditions of degraded areas revitalization demands from the city authorities a continuous monitoring of the needs of various social groups (existing and desirable), researching the inhabitants' level of satisfaction with the quality of their lives and their sense of happiness. At the same time, this requires to develop a system of measurement and quantitative assessment of social and individual happiness in a particular urban area in crisis. Due to a detailed diagnostics of misfortune causes, it is possible to design revitalization measures which can better meet the inhabitants' needs. In this case, it is also important not to lose sight of the issues of the general well-being, employment, security, trust in the community, citizens' participation in city management, etc.

The revival of areas on the basis of the happy city concept must ensure both the implementation of the principles of sustainable territorial development, and the formation of networks and emotional ties in the community. Public spaces should play a leading role in establishing intercultural and inter-generation communications. They should be: innovative (amusement and recreation parks equipped with modern installations, access to $\mathrm{Wi}-\mathrm{Fi}$, and comfortable street furniture); stimulating intellectually (knowledge centres, libraries, and open-air theatres); eagerly sought (sports and children's play areas, courtyards, pet playgrounds). Their functioning should be complemented with all sorts of activities (street performances, concerts, picnics, open debates) designed for the inhabitants of all ages (from children to the elderly), professions, and economic status. In addition, it is worthwhile to form an ecologically friendly environment with provision of quality public services in various spheres of human life. In this regard, educational activities that form an atmosphere of mutual respect and empathy in the city are of special importance.

\section{Learning City}

This concept is premised on the assumption that continuous education of inhabitants lays the basis for sustainable development of areas. Under knowledge economy, citizens who use extensive opportunities of lifelong learning, constantly develop their professional, social and other competencies, are more successful and better prepared for changes in the urban environment. Consequently, it is expedient for the city authorities to organize, in partnership with all stakeholders, an effective system of formal and informal lifelong learning for the inhabitants, regardless of their age, and encourage them in this activity. This should be reflected in the city's strategic vision of attainment of all the Sustainable Development Goals, predominantly: 4 - provision of a quality inclusive and fair education, providing the opportunities of lifelong learning for all; 11 - ensuring inclusiveness, safety, life stability and sustainability of cities and communities.

As defined by UNESCO, a learning city uses its resources in all spheres of life effectively in order to: promote inclusive education of all levels (from basic to higher education); bring back family training and training in the community; develop professional training and inservice training; enhance the use of modern educational technologies; improve the quality of training and provide increased level of educational outcomes; favour the culture of lifelong learning (UNESCO Institute for Lifelong Learning 2017). UNESCO Global Network of Learning Cities unites the cities of the world specializing in the field of lifelong learning. The Network is intended to strengthen the capacity of cities in forming lifelong learning systems through the development of political dialogue, establishing ties, partnerships and exchange of best practices between cities. It devises tools for encouragement of activities in this field and recognition of the progress in creating learning cities (UNESCO Institute for Lifelong Learning 2021).

Degraded urban areas are faced with numerous problems caused mostly by social deprivation. 
Table 2

Characteristics of the elements of public urban revitalization policy in terms of the latest urban development concepts

\begin{tabular}{|c|c|c|c|c|c|}
\hline \multirow[b]{2}{*}{$\#$} & \multirow{2}{*}{$\begin{array}{c}\text { Innovative urban } \\
\text { development } \\
\text { concepts }\end{array}$} & \multicolumn{3}{|c|}{ Elements of urban revitalization policy } & \multirow[b]{2}{*}{$\begin{array}{l}\text { Predominant } \\
\text { indicators }\end{array}$} \\
\hline & & Concern of the policy & $\begin{array}{l}\text { Policy objective } \\
\text { as regards people }\end{array}$ & Policy focal points & \\
\hline 1. & Compact City & $\begin{array}{l}\text { Organization of a compact } \\
\text { multifunctional environment }\end{array}$ & $\begin{array}{l}\text { people in a comfortable } \\
\text { environment }\end{array}$ & $\begin{array}{l}\text { providing high density of housing } \\
\text { in an area; quality and affordable } \\
\text { public services }\end{array}$ & $\begin{array}{l}\text { standards } \\
\text { and quality of life }\end{array}$ \\
\hline 2. & Green City & $\begin{array}{l}\text { Formation of an ecologically- } \\
\text { friendly environment } \\
\text { for human life and activities }\end{array}$ & $\begin{array}{l}\text { well-off and healthy } \\
\text { people }\end{array}$ & $\begin{array}{l}\text { expansion of green plantations, } \\
\text { creation of pedestrian and cycling } \\
\text { paths, pro-ecological educational } \\
\text { activities }\end{array}$ & $\begin{array}{l}\text { quality of life, } \\
\text { environmental } \\
\text { condition }\end{array}$ \\
\hline 3. & Smart City & $\begin{array}{l}\text { Arrangement of urban } \\
\text { space, applying modern } \\
\text { technologies and innovations }\end{array}$ & $\begin{array}{l}\text { people in a comfortable } \\
\text { environment }\end{array}$ & $\begin{array}{l}\text { priming of innovative economy } \\
\text { and stable mobility; security } \\
\text { management; rational use of } \\
\text { resources }\end{array}$ & $\begin{array}{l}\text { standards and } \\
\text { quality of life, } \\
\text { safety level }\end{array}$ \\
\hline 4. & Creative City & $\begin{array}{l}\text { Establishing conditions } \\
\text { for life, activity and } \\
\text { cooperation of creative } \\
\text { people }\end{array}$ & creative people & $\begin{array}{l}\text { development of public spaces } \\
\text { for creativity; support of talented } \\
\text { people and creative industry } \\
\text { entities }\end{array}$ & $\begin{array}{l}\text { quality of life, } \\
\text { level of tolerance } \\
\text { in the community }\end{array}$ \\
\hline 5. & Inclusive City & $\begin{array}{l}\text { Providing a full-fledged } \\
\text { multidimensional inclusion } \\
\text { of all the inhabitants }\end{array}$ & $\begin{array}{l}\text { people in an environment } \\
\text { of accessible public goods }\end{array}$ & $\begin{array}{l}\text { counteraction to social exclusion, } \\
\text { ensuring availability of public } \\
\text { services and spaces, participative } \\
\text { measures }\end{array}$ & $\begin{array}{l}\text { quality of life, } \\
\text { level of social } \\
\text { inclusion }\end{array}$ \\
\hline 6. & Cittaslow & $\begin{array}{l}\text { Realization of an area's } \\
\text { internal potential based } \\
\text { on local identity }\end{array}$ & satisfied, calm people & $\begin{array}{l}\text { support for local culture } \\
\text { and traditions; promotion } \\
\text { of healthy eating, tourism, } \\
\text { and hospitality industry } \\
\end{array}$ & $\begin{array}{l}\text { quality of life, } \\
\text { level of trust, } \\
\text { social cohesion }\end{array}$ \\
\hline 7. & Happy City & $\begin{array}{l}\text { Increasing the level of public } \\
\text { and individual happiness }\end{array}$ & happy people & $\begin{array}{l}\text { organization of activities } \\
\text { and public spaces; promoting } \\
\text { formation of networks } \\
\text { and emotional ties; } \\
\text { environmental protection }\end{array}$ & $\begin{array}{l}\text { level of happiness, } \\
\text { empathy in the } \\
\text { community }\end{array}$ \\
\hline 8. & Learning City & $\begin{array}{l}\text { Promoting the culture } \\
\text { of lifelong learning } \\
\text { for all the inhabitants }\end{array}$ & learning people & $\begin{array}{l}\text { development of educational } \\
\text { infrastructure; ensuring } \\
\text { high-quality lifelong learning } \\
\text { of children and adults }\end{array}$ & $\begin{array}{l}\text { quality of life, } \\
\text { level of education }\end{array}$ \\
\hline
\end{tabular}

Source: author's development

The driving force of urban revitalization is a desire to improve human capital of an area, enriching the inhabitants with new knowledge and developing their qualifications and skills. City authorities, educational and scientific organizations, business entities all have a stake in this. Building the infrastructure for educational services based on modern technologies is an important task of degraded areas revitalization. Essentially, the learning city concept is closely linked to other urban development concepts that were considered in this work, for it substantiates an approach to solving the tasks of forming a green, smart, creative, inclusive urban environment. In turn, it actualizes measures intended to expand access to quality education for children and adults; to facilitate the transformation of municipal and private institutions into learning organizations; to establish partnerships with local employers aimed at professional training and retraining of inhabitants, organization of inservice training; to use the existing infrastructure facilities as educational spaces (libraries, cultural centres, museums) for residents of all generations; to introduce modern information and communication technologies in the educational process (educational online platforms, informal educational networks, digital literacy programmes); to realize educational initiatives as for a number of socially important issues (healthy lifestyle, waste management, rights and obligations of road users, gender equality, intercultural tolerance, etc.); to create incentives and opportunities for the inhabitants' active participation in public life of the city. These measures, being incorporated into urban revitalization programmes, will give them a more integral nature. 


\section{Conclusions}

Summarizing the impact of the chosen urban development concepts on the policy of urban revitalization, it is expedient to consider how each policy addresses various problems of life support, and to formulate its purpose as regards the inhabitants (Table 2). Programme solutions must be individualized depending on the local specifics and state of economic, physical, human and other potentials of the city.

The core of the modern urban revitalization policy should comprise people-oriented programmes of sustainable renewal of areas, aimed to form an urban environment which is: multifunctional, with places of residence, work, and recreation placed close to one another (Compact City); environmentally friendly as a result of expanding green plantations, sustainable nature management, pro-ecological educational measures (Green City); available to all inhabitants without exception (Inclusive City); comfortable due to the introduction of innovations and modern technologies (Smart City); harmonious with nature, surrounding environment, and local traditions (Cittaslow); favourable for the life of creative people (Creative City); and providing a comprehensive lifelong learning (Learning City). At the same time, it is important to seek to ensure a happy life to the inhabitants (Happy City), which requires, among other things, support for networks and emotional ties within the community.

In view of the above considerations, the developers of urban revitalization policies are faced with a complicated problem of choosing specific spheres, on which it is appropriate to focus to achieve a quality urban revitalization. It is important to act in such a way as to cover all the dimensions of sustainable development (economic, social, cultural, environmental) and extend the obtained results to the entire city. Within the limits of the obtained results, it is possible to outline the prospects of further research in the direction of comprehensive innovative practices of urban revitalization, the conditions and challenges of their application in other cities.

\section{References:}

Akotia, J., \& Opoku, A. (2018). Sustainable regeneration project delivery in UK: a qualitative analysis of practitioners' engagement. Journal of Facilities Management, vol. 16(1), pp. 87-100.

Anttiroiko, A. V., \& de Jong, M. (2020). The Inclusive City: the theory and practice of creating shared urban prosperity. Cham: Springer International Publishing, $127 \mathrm{p}$.

Boussaa, D. (2018). Urban regeneration and the search for identity in historic cities. Sustainability, vol. 10(1), pp. $1-16$.

Brdulak, A., \& Brdulak, H. (Eds.). (2017). Happy City - how to plan and create the best livable area for the people. Cham: Springer International Publishing, $332 \mathrm{p}$.

Bryx, M., Lipiec, J., \& Rudzka, I. (2015). Green urban regeneration projects. Warsaw: CeDeWu, 126 p.

Cittaslow International head office (2021). Cittaslow. International network of cities where living is good. Available at: https://www.cittaslow.org.

European Green Capital Secretariat (2021). Winning Cities. European Green Capitals Available at: https://ec.europa.eu/environment/europeangreencapital/winning-cities.

Eurostat (2010). Combating poverty and social exclusion: a statistical portrait of the European Union 2010. Luxembourg: Publications Office of the European Union, 111 p.

Florida, R. (2012). The rise of the creative class. Revisited. New York: Basic Books, 483 p.

Garcia-Fuentes, M. A., Quijano, A., de Torre, C., Garcia, R., Compere, P., Degard, C., \& Tome, I. (2017). European cities characterization as basis towards the replication of a smart and sustainable urban regeneration model. Energy Procedia, vol. 111, pp. 836-845.

Giffinger, R., \& Pichler-Milanović, N. (2007). Smart cities: Ranking of European medium-sized cities. Available at: http://www.smart-cities.eu/download/smart_cities_final_report.pdf

Jacobs, J. (2016). The death and life of great American cities. Reissue ed. New York: Vintage, 462 p.

Jang, H. J., \& Jung, T. (2015). Go slow and curvy: Understanding the philosophy of the Cittaslow slowcity phenomenon. Cham: Springer International Publishing, $176 \mathrm{p}$.

Jaszczak, A., Kristianova, K., Pochodyła, E., Kazak, J. K., \& Młynarczyk, K. (2021). Revitalization of public spaces in Cittaslow towns: recent urban redevelopment in Central Europe. Sustainability, vol. 13(5), pp. 1-24.

Korkmaz, C., \& Balaban, O. (2020). Sustainability of urban regeneration in Turkey: Assessing the performance of the North Ankara urban regeneration project. Habitat International, vol. 95, pp. 1-14.

Kusiak, J. (2019) Revitalizing urban revitalization in Poland: towards a new agenda for research and practice. Urban Development Issues, vol. 63, pp. 17-23.

Landry, C. (2012). The creative city: A toolkit for urban innovators. 2nd ed. London: Earthscan, $350 \mathrm{p}$.

Lehmann, S. (2019). Urban regeneration. A manifesto for transforming UK cities in the age of climate change. London: Palgrave Macmillan, 229 p.

Montgomery, C. (2013). Happy city: Transforming our lives through urban design. London: Macmillan, 359 p. 
Vol. 7 No. 3, 2021

OECD (2012). Compact city policies: a comparative assessment. Paris: OECD Publishing, $284 \mathrm{p}$.

Oyekunle, O. A. (2017). The contribution of creative industries to sustainable urban development in South Africa. African Journal of Science, Technology, Innovation and Development, vol. 9(5), pp. 607-616.

Roberts, P., Sykes, H., \& Granger, R. (Eds.). (2017). Urban regeneration. 2nd ed. London: Sage, 360 p.

Ruming, K. (ed.). (2018). Urban regeneration in Australia: policies, processes and projects of contemporary urban change. London - New York: Routledge, 398 p.

Tubridy, D. (2021). The green adaptation-regeneration nexus: innovation or business-as-usual? European Planning Studies, vol. 29(2), pp. 369-388.

UNESCO Institute for Lifelong Learning (2017). Learning Cities and the SDGs: a guide to action. Available at: https://unesdoc.unesco.org/ark:/48223/pf0000260442

UNESCO Institute for Lifelong Learning (2021). UNESCO Global Network of Learning Cities. Available at: https://uil.unesco.org/lifelong-learning/learning-cities

Wolfram, M. (2019). Assessing transformative capacity for sustainable urban regeneration: A comparative study of three South Korean cities. Ambio, vol. 48(5), pp. 478-493.

Yi, Z., Liu, G., Lang, W., Shrestha, A., \& Martek, I. (2017). Strategic approaches to sustainable urban renewal in developing countries: A case study of Shenzhen, China. Sustainability, vol. 9(8), pp. 1-19.

Zheng, W. (2017). A multi-scale decision support framework for sustainable urban renewal in high-density cities: a case of Hong Kong. Hong Kong: The Hong Kong Polytechnic University, 227 p. 